EESTI NSV TEADUSTE AKADEEMIA TOIMETISED. VII KOIDE

BIOLOOGILINE SEERIA. 1958, NR. 1

ИЗВЕСТИЯ АКАДЕМИИ НАУК ЭСТОНСКОИ ССР. ТОМ VII

ОЕРИЯ БИОЛОГИЧЕСКАЯ. 1958, № 1

\title{
ОБ АНТИТОКСИЧЕСКОМ ДЕЙСВИИ ОСНОВНЫХ ПРОТИВОТУБЕРКУЛЕЗНЫХ ПРЕПАРАТОВ
}

\author{
Г. А. МИХАИЛЕЦ, \\ кандидат медицинских наук
}

Все клиницисты единодушно отмечают, что применение стрептомицина, фтивазида и ПАСК у больных с острыми формами туберкулеза приводит к быстрой дезинтоксикации организма. У туберкулезных больных под влиянием антибактериальной терапии быстро улучшается самочувствие, снижается температура, повышается аппетит, наблюдается прибавление веса. Общие симптомы уменьшения интоксикации сопровождаются восстановлением нарушенного обмена веществ, нормализацией функционального состояния нервной и сердечно-сосудистой систем, печени, желудочно-кишечного тракта, восстановлением нормальной картины крови и т. д.

На основании этих наблюдений сложилось представление, что стрептомицин, фтивазид и ПАСК обладают антитоксическим действием. Однако дезинтоксикация организма, наблюдаемая при применении противотуберкулезных препаратов, может зависеть от нескольких причин. Во-первых, существенное значение в механизме антитоксического действия противотуберкулезных средств может иметь их бактериостатическое действие, в результате которого происходит значительное ослабление жизнедеятельности туберкулезных бацилл, а отсюда и уменьшение количества выделяемых ими токсинов. Во-вторых, стрептомицин, фтивазид и ПАСК могут непосредственно обезвреживать токсины туберкулезных палочек, вступая с ними в химические реакции. Наконец, не исключена возможность, что под влиянием противотуберкулезных препаратов сам макроорганизм становится менее чувствительным к продуктам жизнедеятельности туберкулезных бацилл и продуктам распада тканей.

Имеющиеся в литературе данные о механизме антитоксического действия противотуберкулезных препаратов очень скудны и довольно противоречивы.

Р. О. Драбкина и Т. С. Гинзбург (1956) в опытах на больных туберкулезом морских свинках исследовали антитоксическое действие стрептомицина и пришли к выводу, что антибиотик не обладает способностью предотвратить или ослабить туберкулиновый шок, наступающий после введения минимальных смертельных доз туберкулина или убитых туберкулезных бацилл.

В то же время Г. С. Кану (1955) с помощью стрептомицина удалось в значнтельной степени смягчить течение сывороточного анафилактического шока.

Г. Е. Платонов, Э. Л. Блох и Н. Е. Прокопенко (1949) исследовали действие лейкоцитов в присутствии стрептомицина на способность туберкулина вызывать кожную реакцию у туберкулезных больных. Согласно их исследованиям, лейкоциты эксудата кролика за трое суток настаивания с туберкулином, к которому прибавлен стрептомнцин (3 единицы на 1 мл), не уменьшают его активности.

О значительной инактивации туберкулина при добавлении к нему раствора гидразида изоникотиновой кислоты с последующим содержанием полученной смеси в термостате в течение 15 суток при $37^{\circ}$ сообщает Фуст (1953). У больных туберкулезом 
кроликов внутрикожное введение такой смеси вызывает значительно менее выраженную кожную реакцию, чем введение чистого туберкулина соответствующего разведения, также подвергавшегося длительному подогреванию в термостате.

В протнвоположность этим исследованиям, Куратоло (1952) не наблюдал нейтрализации туберкулина при добавлении изониазида, если смесь консервировалась в течение многих дней в холодильнике.

По данным Фуста и соавторов (1952), 4-недельное лечение морских свинок гидразидом изоникотиновой кислоты значительно понижает их чувствительность к туберкулину: леченные жнвотные слабо реагируют на подкожное введение такой дозы туберкулина, которая является смертельной для контрольных морских свинок.

Что касается фтивазида и ПАСК, то работ, посвященных анализу их антитоксического действия по отношению к туберкулину, в литературе вообще нет.

Для выяснения механизма антитоксического действия стрептомицина, фтивазида и ПАСК нами было поставлено 3 опыта на 67 больных туберкулезом морских свинках. Заражение животных во всех случаях производилось подкожным введением вирулентной культуры Mycobacterium tuberculosis Bovinus № 8 в дозе 0,0001 мг.

В первом опыте было исследовано влияние предварительного насыщения организма противотуберкулезными препаратами на течение туберкулинового шока у больных туберкулезом морских свинок.

Поскольку в клинике отчетливые симптомы снижения интоксикации наблюдаются уже в течение первой недели лечения противотуберкулезными средствами, в проведенных нами опытах мы вводили стрептомицин, фтивазид и ПАСК в течение последних 5-7 дней до инъекции туберкулина. Более продолжительное введение антибактериальных препаратов для выявления поставленной задачи, очевидно, является нецелесообразным, так как в случаях длительной терапии резко уменьшается количество туберкулезных бацилл в организме, меняется картина заболевания, что, естественно, отражается и на чувствительности организма к туберкулину.

Bсе противотуберкулезные препараты вводились в дозах, близких к оптимальным терапевтическим, употребляемым для лечения экспериментального туберкулеза у морских свинок.

В первом опыте стрептомицин, фтивазид и ПАСК давались последний раз за 2 часа до инъекции туберкулина, которая производилась на 44 день после заражения морских свинок. К этому времени все животные отчетливо реагировали на внутрикожное введение туберкулина. Шок вызывался внутрибрюшинным введением $50 \%$ раствора туберкулина в количестве 0,5 мл.

Результаты опыта представлены в табл. 1.

Из приведенной таблицы видно, что при такой постановке опыта стрептомицин, фтивазид и ПАСК не оказали никакого благотворного действия на течение туберкулинового шока. Наоборот, животные, получавшие ПАСК, гибли даже несколько скорее, чем контрольные морские свинки.

В следующем опыте, результаты которого даны в табл. 2, препараты вводились в течение последних 5 дней перед инъекцией туберкулина, причем в день инъекции стрептомицин, фтивазид и ПАСК давались трижды: за 2 часа до и через 3 и 6 часов после инъекции. Разовая доза стрептомицина была увеличена до 15000 единиц, а доза ПАСК, наоборот, уменьшена до 250 мг на животное, что составляет приблизительно 0,5 г/кг веса.

Туберкулин (цельный) вводился на 46 день с момента заражения животных в количестве 0,5 мл. По данным Р. О. Драбкиной и Т. С. Гинзбург (1956), эта доза туберкулина является минимальной, вызывающей смерть у всех больных туберкулезом морских свинок. 
Tаблица 1

Влияние предварительного введения противотуберкулезных препаратов на исход туберкулинового шока у больных туберкулезом морских свинок

\begin{tabular}{l|c|c|c}
\hline Препараты & $\begin{array}{c}\text { Дозы и способ введения } \\
\text { препарата }\end{array}$ & $\begin{array}{c}\text { Количество } \\
\text { животных } \\
\text { в опыте }\end{array}$ & Результаты опыта \\
\hline Стрептомицин & $\begin{array}{c}\text { Подкожно последние 7 } \\
\text { дней до инъекцин туберку- } \\
\text { лина по 10000 ед. на жи- } \\
\text { вотное }\end{array}$ & 4 & $\begin{array}{c}\text { Погнбли 2 свинки через } \\
\text { час после инъекцни ту- } \\
\text { беркулина }\end{array}$ \\
\hline Фтивазид & $\begin{array}{c}\text { Внутрь в те же сроки по } \\
25 \text { мг на жнвотне }\end{array}$ & 5 & $\begin{array}{c}\text { Погибла 1 свинка через } \\
\text { час }\end{array}$ \\
\hline ПАСК & $\begin{array}{c}\text { Внутрь в те же сроки по } \\
\text { г/кг веса }\end{array}$ & 4 & $\begin{array}{c}\text { Погибли 2 свинки через } \\
\text { часов и 1 через 23 часа }\end{array}$ \\
\hline Контроль & $\begin{array}{c}\text { Внутрь по 2 мл воды в те } \\
\text { же сроки }\end{array}$ & 4 & $\begin{array}{c}\text { Погибла 1 свинка через } \\
\text { часов и 1 через 41 час }\end{array}$
\end{tabular}

Таблица 2

Влияние стрептомицина, фтивазида и ПАСК на исход туберкулинового шока у морских свинок при профилактическом и лечебном применении препаратов

\begin{tabular}{l|c|c|c}
\hline Препараты & $\begin{array}{c}\text { Дозы и способ введения } \\
\text { препарата }\end{array}$ & $\begin{array}{c}\text { Количество } \\
\text { животных } \\
\text { в опыте }\end{array}$ & Результаты опыта \\
\hline Стрептомицин & $\begin{array}{c}\text { Подкожно по 15000 еди- } \\
\text { ниц в течение 5 дней до } \\
\text { инъекцин туберкулина и че- } \\
\text { рез 3 и 6 часов после инъ- } \\
\text { екции }\end{array}$ & 7 & $\begin{array}{c}\text { Bсе свинки погибли в те- } \\
\text { чение 18 часов }\end{array}$ \\
\hline Фтивазнд & $\begin{array}{c}\text { Внутрь в те же сроки по } \\
25 \text { мг на животное }\end{array}$ & 7 & $\begin{array}{c}\text { Все свннки погибли в те- } \\
\text { чение 18 часов }\end{array}$ \\
\hline ПАСК & $\begin{array}{c}\text { Внутрь в те же сроки по } \\
250 \text { мг на животное }\end{array}$ & 6 & $\begin{array}{c}\text { Все свннки погибли в те- } \\
\text { чение 18 часов }\end{array}$ \\
\hline Қонтроль & $\begin{array}{c}\text { Внутрь по 2 мл воды в те } \\
\text { же срокн }\end{array}$ & 6 & $\begin{array}{c}\text { Все свннки погибли в те- } \\
\text { чение 18 часов }\end{array}$
\end{tabular}

Результаты опыта убедительно показывают, что стрептомицин, фтивазид и ПАСК не влияют на исход туберкулинового шока также и в том случае, когда они вводятся не только профилактически, но и после инъекции туберкулина. Не наблюдалось никаких различий и в картине течения шока у подопытных морских свинок по сравнению с контрольными.

В третьем опыте (табл. 3) наряду с насыщением животных противотуберкулезными препаратами, как это имело место во втором опыте, морским свинкам вводился туберкулин, находившийся длительное время в контакте с одним из применявшихся препаратов. Для этого за 4 суток до производства опыта к туберкулину прибавлялись стрептомицин, фти- 
Табмича \&

Влияние стрептомицина, фтнвазида и ПАСК на течение туберкулинового шока у морских свинок при введении животным туберкулина в смеси с одним из этих препаратов

\begin{tabular}{|c|c|c|c|c|}
\hline Препараты & $\begin{array}{c}\text { Дозы и способ введения } \\
\text { препарата }\end{array}$ & $\begin{array}{r}\text { Количество } \\
\text { препарата, } \\
\text { прнбавлен- } \\
\text { ного к } 1 \text { мл } \\
\text { туберкулина }\end{array}$ & $\begin{array}{l}\text { Қоличе- } \\
\text { ство жи- } \\
\text { вотных } \\
\text { в опыте }\end{array}$ & Результаты опыта \\
\hline Стрептомицин & $\begin{array}{l}\text { Подкожно по } 15000 \\
\text { единиц ежедневно в те- } \\
\text { чение } 5 \text { дней до инъек- } \\
\text { ции туберкулина и через } \\
3 \text { и } 6 \text { часов после инъек- } \\
\text { ции }\end{array}$ & 250 ед & 6 & $\begin{array}{l}\text { Все свннки погибли } \\
\text { в теченне } 18 \text { часов }\end{array}$ \\
\hline Фтивазид & $\begin{array}{c}\text { Внутрь в те же } \\
\text { срокн по } 25 \text { мг на } \\
\text { животное }\end{array}$ & $0,2 \mathrm{Mr}$ & 6 & $\begin{array}{l}\text { Все свинки погибли } \\
\text { в течение } 18 \text { часов }\end{array}$ \\
\hline ПІАСК & $\begin{array}{c}\text { Внутрь в те же } \\
\text { сроки по } 250 \mathrm{Mr} \\
\text { на животное }\end{array}$ & $0,25 \mathrm{Mr}$ & 6 & $\begin{array}{l}4 \text { свинки погибли } \\
\text { в течение } 18 \text { часов, } \\
1 \text { - через } 26 \text { и } 1- \\
\text { через } 46 \text { часов }\end{array}$ \\
\hline Контроль & $\begin{array}{c}\text { Внутрь в те же } \\
\text { сроки по } 2 \text { мл } \\
\text { воды }\end{array}$ & - & 6 & $\begin{array}{l}\text { Все свинки погибли } \\
\text { в теченне } 18 \text { часов }\end{array}$ \\
\hline
\end{tabular}

вазид или ПАСК и полученные таким образом смеси туберкулина с антибактериальным препаратом помещались в термостат при температуре $37^{\circ}$.

Контрольным животным вводили чистый туберкулин, содержавшийся в течение 4 суток в термостате.

Оказалось, что и в условиях этого опыта стрептомицин, фтивазид и ПАСК заметным образом не повлияли на течение и исход туберкулинового шока. Правда, в случаях применения парааминосалициловой кислоты 2 свинки из 6 жили несколько дольше, чем контрольные животные, однако, учитывая результаты первых двух опытов и тот факт, что большинство животных (4 из 6), получавших туберкулин в смеси с ПАСК, погибло также в течение 18 часов при явлениях классического туберкулинового шока, следует считать эту разницу не имеющей существенного значения. В пользу такого утверждения говорят и клинические данные, которые отчетливо указывают на значительно более выраженное антитоксическое действие стрептомицина и фтивазида по сравнению с парааминосалициловой кислотой.

Таким образом, проведенные исследования отчетливо показывают, что насыщение организма больных туберкулезом морских свинок стрептомицином, фтивазидом или ПАСК не делает их менее чувствительными к туберкулину. В изученных дозах противотуберкулезные препараты, будучи добавлены in vitro к туберкулину, не уменьшают его токсических свойств по отношению к больным туберкулезом животным.

Эти факты позволяют сделать вывод, что дезинтоксикация организма, наступающая при применении противотуберкулезных препаратов в случаях успешной терапии различных форм туберкулеза, является следстви- 
ем их антибактериального действия, а не результатом обезвреживания токсинов или влияния препаратов на макроорганизм. Уменьшение бациллярной инвазии позволяет организму более эффективно мобилизовать защитные механизмы, которые и обусловливают обезвреживание токсинов.

\title{
ЛИТЕРАТУРА
}

Д р а бкин а Р. О. и Гинз бург Т. С., 1956. К механизму действия стрептомнцина. ЖМЭИ, № 5, стр. 43-47.

К ан Г. С., 1955. Физиологические предпосылки к пониманию механизма лечебного действия стрептомицина. Тезисы докладов к научной сессии Ленинградского научн.-иссл. ин-та туберкулеза, Л., стр. 81-83.

П л а тонов Г. Е., Блох Э. Л. и Прокопенко Н. Е., 1949. Влияние стрептомицина на клеточную реакцию при туберкулезе. В сб.: «Стрептомицин в терапин туберкулеза». Труды АМН СССР, ин-тут туберкулеза, вып. 5, М., стр. 35-42.

Curatolo, A., 1952. Allergia tuberculinika ed antibiotica. Atti Soc. Lombarda Sci. Med. e Biol., 7, стр. 348-352.

Fu s t, B., 1953. Tuberculin-Inaktivierung durch Rimifon. Schweiz. med. Wochenschr., 83, Nr. 26, стр. 18--22.

Fust, B., S tud e r, A., B öh n i, E. 1952. Experimentelle Erfahrungen mit dem Antituberculoticum Rimifon. Schweiz. Ztschr. Tuberk., 9, Nr. 4, crp. 226-242.

Ннститут экспериментальной и клинической медицины Поступила в редакцию Академии наук Эстонской ССР 10 VIII 1957

\section{PEAMISTE TUBERKULOOSIVASTASTE PREPARAATIDE ANTITOKSILISEST TOIMEST}

\author{
G. Mihhailets, \\ meditsilniteaduste kandidaat
}

\section{Resümee}

Uuriti streptomütsiini, ftivasiidi ning PAS-i toimet tuberkuliini šoki kulule tuberkuloosihaigetel merisigadel. Preparaate manustati terapeutilistes annustes 5-7 päeva enne tuberkuliini injektsiooni ning 3 ja 6 tundi pärast tuberkuliini injektsiooni. Óhes katses, lisaks loomade organismi küllastamisele tuberkuloosivastaste preparaatidega, manustati merisigadele tuberkuliini, mis oli 4 ööpäeva kontaktis ühega uuritavaist aineist.

Uurimised näitasid, et tuberkuloosihaigete merisigade organismi küllastamine streptomütsiini, ftivasiidi vōi PAS-iga ei tee neid vähemtundlikuks tuberkuliini suhtes. Tuberkuloosivastased preparaadid, mis uuritud annustes on lisatud tuberkuliinile in vitro, ei vähenda tuberkuliini toksilisi omadusi tuberkuloosihaigetele katseloomadele.

\author{
Eesti NSV Teaduste Akadeemia \\ Eksperimentaalse ja Kliinilise Meditsiini Instituut \\ Saabus toimetusse \\ 10. VIII 1957
}

\section{ACTION ANTITOXIQUE DE QUELQUES MÉDICAMENTS ANTITUBERCULEUX}

\section{G. Mikhaïletz}

\section{Résumé}

On a étudié l'action de la streptomycine, du phtivazide et de l'acide paraaminosaly. cilique sur le choc provoqué par la tuberculine chez les cobays tuberculeux. Les susdits médicaments ont été appliqués en doses thèrapeutiques 5-7 jours avant l'injection de la tuberculine et $3-6$ heures après l'injection.

Pour provoquer le choc, on s'est servi dans un des expériments - à part la saturation de l'animal par les médicaments antituberculeux - de la tuberculine ayant été en contact pendant 4 jours avec un des médicaments étudiés.

Les investigations ont montré que la saturation de l'organisme des cobays tuberculeux par la streptomycine, le phtivazide et l'acide paraaminosalycilique ne les rend pas moins sensibles à la tuberculine.

Les susdits médicaments, étant ajoutés, en doses thérapeutiques, à la tuberculine in vitro ne réduisent pas son action toxique sur l'organisme de l'animal tuberculeux. 